\title{
Climate risk and food availability in Guatemala
}

\author{
Renato Vargas ${ }^{1 *}$, Maynor Cabrera ${ }^{2}$, Martin Cicowiez $^{3}$, Pamela Escobar ${ }^{1}$, Violeta Hernández ${ }^{1}$, \\ Javier Cabrera $^{4}$ and Vivian Guzmán ${ }^{1}$ \\ ${ }^{1}$ CHW Research, Guatemala City, Guatemala; ${ }^{2}$ Fundación Economía para el Desarrollo (FEDES), \\ Guatemala City, Guatemala; ${ }^{3}$ Labor, and Social Studies, Center for Distributive, Universidad Nacional de \\ La Plata, Argentina and ${ }^{4}$ Instituto Centroamericano de Estudios Fiscales (ICEFI), Guatemala City, \\ Guatemala \\ ${ }^{\star}$ Corresponding author. Email: renovargas@gmail.com
}

(Submitted 14 September 2017; revised 28 February 2018, 2 May 2018; accepted 10 May 2018)

\begin{abstract}
In this paper, we use a computable general equilibrium model to simulate the effects of drought and a decrease in agricultural productivity caused by climate change in Guatemala. A reduction in agricultural productivity would mean a considerable drop in crop and livestock production, and the resulting higher prices and lower household income would mean a significant reduction in the consumption of agricultural goods and food. The most negative effects of a drought would be concentrated in agriculture, given its intensive use of water. Because agricultural production is essential to ensuring food availability, these results suggest that Guatemala needs a proper water-distribution regulatory framework.
\end{abstract}

Keywords: Agricultural employment; climate change; computable general equilibrium; farm household; farm input markets; natural resource

JEL Classification: R15, R22, Q12

\section{Introduction}

If water - one of the most important inputs in agricultural production - should become scarce, what would the impact be on a food-insecure country like Guatemala?

In recent years, shifts in precipitation and in water availability, along with increasing demographic pressures, have made the answer to this question particularly significant. Between 1950 and 2006, annual precipitation in Guatemala declined by 2.7 per cent, an effect which - combined with high deforestation - could worsen in the future (UNESCO, 2012). ${ }^{1}$ At the same time, Guatemala's population grew at an annual

\footnotetext{
${ }^{1}$ In 2010, Guatemala had 3.72 million hectares of forest cover, equivalent to 34.7 per cent of the total land area. By 2015, the forest area was equivalent to 33 per cent of the total land area (FAO, 2017). Forests are important to the Guatemalan population because they are suppliers of wood, firewood, brushwood and other non-timber products. The causes of deforestation and degradation of forests in Guatemala are varied, reflected in the annual loss of 41,658.7 hectares of forest, which means an annual deforestation rate of 1.1 per cent (IARNA, 2012).
}

(C) Cambridge University Press 2018 
rate of 2.0 per cent, one of the highest rates among countries in Latin America and the Caribbean (World Bank, 2016). That, in turn, places greater demands on food supply.

Guatemala is already facing food-insecurity challenges. Nationally, 46.5 per cent of children under five years of age live with chronic malnutrition, and the figure reaches 53 per cent in rural areas (MSPAS et al., 2016). As of 2015, 15.6 per cent of Guatemala's population lived below minimum dietary levels, an increase from 14.9 per cent in 1991 (UN, 2016), evidence that the situation is not improving.

Food insecurity is linked to low yields in the production of grains, low investment in technology, and high transaction costs for local markets, as well as low wages and a high percentage of low-skilled workers in rural areas. In fact, yields for grains average 2.1 tons per hectare in Guatemala, below the Latin American average of 2.9 and the world average of 3.3 (FAO, 2017). A third of Guatemala's labor force is employed in agriculture, though only 6.8 per cent of these workers have formal jobs; the agricultural sector, meanwhile, makes extensive use of unskilled labor (INE, 2011). Furthermore, a high percentage of Guatemala's grain supply is imported, making Guatemala vulnerable to increases in world prices. In 2010, for instance, Guatemala imported 99.7 per cent of its wheat, 69.5 per cent of its rice, and 21.3 per cent of its corn. Rosegrant et al. (2014) showed that prices for these commodities will increase by 88, 79 and 104 per cent respectively by 2050. The implications of these projections for grain supply and food availability in Guatemala are worrisome. Even with elevated percentages of grain imports, a large portion of the population in rural areas grow maize for own consumption or buy locally-produced corn because they are disconnected from larger distribution networks that carry imports. According to the Living Standards Measurement Study (INE, 2011), smallholder farmers produced an average of 1,950 kg of white corn each during the last harvest, of which they set aside an average of $663 \mathrm{~kg}$, or 34 per cent, for their own families' consumption. A total of 33 per cent of households in the country have some sort of agricultural production. Imports of this staple crop consist mainly of yellow sweet corn, which caters to a different target market of mainly urban consumers.

The main sources of water demand are agriculture, energy production, industries and human consumption. As the demand for water increases around the world, it is very likely that the availability of fresh water in many regions will decrease due to climate change. Global climate change is expected to exacerbate current and future stresses on water resources from population growth and land use and increase the frequency and severity of droughts and floods. It is anticipated that climate change will affect the availability of water resources through changes in rainfall distribution, soil moisture, glacier and ice/snow melt, and river and groundwater flows (UNESCO, 2013).

Scientists have largely explored the impact that climate change has on agriculture because 'water-related hazards account for 90 per cent of every natural hazard and their frequency and intensity is generally rising' (UNESCO, 2013). This means that spatial and temporal patterns of precipitation and water availability have been changing, and it implies more dry spells, droughts or floods across the world. These events could have socioeconomic effects as the increasingly erratic rainfall and high temperatures, among other factors, can significantly reduce food availability in low-latitude countries (IPCC, 2014).

In this paper, we focus on water availability for the agricultural sector because agricultural production is essential to ensure domestic food production. Climate variability 
may further restrict the supply of water to agriculture in light of Guatemala's insufficient investment in reservoirs and related infrastructure projects as well as its failure to protect natural areas that are important to fresh-water production. Between 1995 and 2014, Guatemala suffered more than most other countries from extreme weather events (Kreft et al., 2015), which had and will continue to have an impact on agricultural yields. By 2030, corn yields are projected to vary between -6.7 and -3.8 per cent, bean yields from -6.9 to 1.5 per cent, and rice yields from -10.4 to -7.5 per cent (CEPAL, 2013).

Water-use regulation is lax in Guatemala, and public utilities and irrigation districts participate minimally in water supply, leaving various agents to procure water by private means, a process that means greater cost, greater uncertainty, and less efficient distribution. Vargas (2009) shows that while 78 per cent of urban and 43 per cent of rural households in Guatemala are connected to a water distribution network, they faced 4 to 5 days of water scarcity per month in the national average (in some rural areas up to 8 or 9 days) and 5 per cent of connected households have to buy water from a water tanker truck. According to the Ministry of Agriculture (MAGA, 2013), 236,243 hectares of arable land have a high need for irrigation and 895,257 hectares of agricultural land have a medium need for irrigation.

Low precipitation in some seasons means that, during sustained dry periods, water must be drilled for, pumped, diverted, and transported, all of which are expensive. Industries such as agriculture that use water more intensively face an important economic decision: whether to continue production or reallocate labor and capital to other industries despite the resulting impact on food production. Water availability is, therefore, crucial to Guatemala's economic development. To evaluate the impact of water scarcity on the Guatemalan economy, we implemented a computable general equilibrium (CGE) model that incorporated details of Guatemalan agriculture to provide a multidimensional answer to the potential effects of water scarcity. The model's general-equilibrium specification reflects Guatemala's economic structure and captures interactions among producers and consumers in a market-based economy. We assess the potential effects of a drop in agricultural productivity as a result of climate change (first scenario) or a severe drought (second scenario).

In this paper, we contribute to the literature with evidence regarding the impacts of climate change-related shocks on food availability in a developing and food-insecure country such as Guatemala.

\section{Literature review}

According to a comprehensive study conducted in Guatemala (IARNA et al., 2015), food-security issues are a multidimensional problem, with various elements affecting food availability, access, and benefits.

Local researchers have not used CGE models to analyze the food-security situation, though non-CGE studies have been undertaken in the past (e.g. Palmieri and Delgado, 2011). CGE models can simultaneously evaluate various aspects of food-security problems, including food prices, income and expenditures, and the economy-wide implications of food policies (e.g. Rutten et al., 2013). In general, applications of CGE models to the Guatemalan situation have been few. Vásquez (2008) applied an integrated macro-micro model to analyze Millennium Development Goals (MDG), and Cabrera and Delgado (2010) implemented the Model of Exogenous Shocks and Economic and Social Protection (MACEPES) to analyze the impact of external shocks on poverty and inequality. 
An increasing wealth of literature applies macro-models to assessments of climate change and food insecurity. Wiebelt et al. (2013), for example, examined local and global climate-change effects in Yemen, focusing on agricultural production, household income, and food security. They found that those hit hardest by losses were net buyers of food (even among food producers) and that, at the macro level, the positive effects of climate-change-mitigation efforts on yields and GDP were cancelled out by their cost. Montaud et al. (2017) applied macro-modeling to the effects of climate variability on agriculture in Niger and found that, although GDP and other economic indicators would all be affected negatively, investments in rural road infrastructure and modern crop varieties could offset those effects in part. Sudarshan et al. (2017) quantified the effects of climate change on the Nepalese economy, finding that the population's high dependence on subsistence farming increased poverty and further strained the social-welfare system. Finally, Sassi and Cardaci (2013) assessed the impact of changes in rainfall patterns on food availability in Sudan, finding a reduction in cereal supply, marked cereal-inflation pressure, and income contraction, with greater negative effects on the poorest households and a country-wide deterioration of economic performance.

Traditionally, CGE models of water-resource issues have analyzed the effects of restricting water use in agriculture and transferring water to the environment or other industries. Water is normally included as a fixed share of the value of land (e.g. Seung et al., 1997), or as a factor of production that is calculated together with land in a fixed ratio in assessing agricultural crops (e.g. Berck et al., 1990).

Other studies have considered water a commodity provided by an industry, which transforms 'raw' water into treated form (Tirado et al., 2010; Juana et al., 2011; Watson and Davies, 2011); in these cases, the water industry is viewed as a productive activity that provides treated water to other industries. These approaches, however, require that most of a country's water use be accounted for in water titles registered and monitored by regulators or as transactions between the water-producing industry and other users. In the case of Guatemala, some titles exist, but they do not represent most of the country's water use, which is for the most part unregulated. We therefore turned to Banerjee et al. (2016) and used an approach that links water used as an input to production with estimated changes in water stocks in a 'satellite account'. This paper contributes to the application of these developments to the case of a vulnerable, food-insecure country like Guatemala.

\section{Model and data}

\subsection{Model}

We applied a version of the PEP 1-1 Model developed by Decaluwé et al. (2013) with extensions for the inclusion of water based on Banerjee et al. (2016). ${ }^{2}$

Certainly, modelling water in an economy-wide framework poses its own set of challenges, particularly in the case of non-registered water, which is water that is not distributed by a water utility company and is used primarily by the agricultural sector. In our extension PEP-1-1, it is assumed that water not supplied by the water utility company and not subject to an economic transaction has, initially, a price of zero. Then, depending on supply and demand conditions, the price of water can become greater than zero.

\footnotetext{
${ }^{2}$ The model code, written in the GAMS language, and its Guatemalan dataset are available from the authors upon request.
} 
Mathematically, equations (1)-(7) show the treatment for water used in agriculture in the extended PEP-1-1 model.

$$
\begin{aligned}
\mathrm{WATD}_{j} & =i \text { wat }_{j} \cdot \mathrm{XST}_{j} \\
\mathrm{PP}_{j} \cdot \mathrm{XST}_{j} & =\mathrm{PVA}_{j} \cdot \mathrm{VA}_{j}+\mathrm{PCI}_{j} \cdot \mathrm{CI}_{j}+\mathrm{PWAT}_{j} \mathrm{WATD}_{j} \\
\sum_{j} \mathrm{PWTD}_{j} & \leq \text { wats } \\
\left(\sum_{j} \mathrm{WATD}_{j}-\text { wats }\right) \mathrm{PWAT} & =0 \\
\mathrm{YWAT} & =\sum_{j} \mathrm{PWAT}_{j} \mathrm{WATD}_{j} \\
\mathrm{YIWAT}_{a g} & =\text { shrywat }_{a g} \cdot \mathrm{YWAT}
\end{aligned}
$$

where

$j$ : activities or industries with information on the use of unregistered water

$\mathrm{CI}_{j}$ : total intermediate consumption of industry $j$

$\mathrm{PCI}_{j}$ : intermediate consumption price index of industry $j$

$\mathrm{PP}_{j}$ : industry $j$ unit cost

$\mathrm{PVA}_{j}$ : price of industry $j$ value added

PWAT: water price

$\mathrm{VA}_{j}$ : value added of industry $j$

$\mathrm{WATD}_{j}$ : water demand

$\mathrm{XST}_{j}$ : total aggregate output of industry $j$

YIWAT $_{a g}$ : institutional income from water

YWAT: total income from water

$i$ wat $_{j}$ : water consumed per unit of output in industry $j$

shrywat $_{a g}$ : share of water income received by agent $a g$

wats: (exogenous) water supply

Equation (1) states that (unregistered) water use in agricultural - including crops and livestock - and non-agricultural sectors such as forestry and fishing is proportional to the corresponding output from agricultural sectors. Equation (2) shows the zero profit condition for the productive sectors, which includes payments for water used (see last term). Equations (3)-(5) represent the market equilibrium conditions in the unregistered water market. As shown, one of the following two situations can be observed: (i) water supply is larger than water demand and the price of water is zero, or (ii) water demand is equal to water supply and the price of water is positive. 
In the case of Guatemala, given the available information in the Guatemalan System of Environmental-Economic Accounting (SEEA), ${ }^{3}$ it is assumed that water supply is initially larger than water demand and the price of water is zero. Then, as water supply decreases in a drought scenario, restriction (3) becomes binding and the price of water becomes positive. In turn, a positive price of water generates a cost for producers and income for water owners, as shown in equations (6) and (7). In practice, this additional cost may represent a cost of extracting underground water.

In model calibration, we assumed that water-derived income is allocated across institutions in proportion to their ownership of land, which is determined by the exogenous shrywat $_{a g}$ parameter in equation (7). Needless to say, income from water is added to other sources of institutional income. Besides, another effect resulting from reduction in water availability is a fall in total factor productivity (TFP).

At the macro level, our CGE model - like others - requires the specification of the equilibrating mechanisms ('closures') for three macroeconomic variables: government, savings-investment, and the balance of payments. In all simulations, the following macroeconomic closure rules are applied: (1) government consumption is adjusted to maintain a constant level of government savings ${ }^{4}$ and to reflect difficulties which, in the Guatemalan context, would entail passing tax reforms; (2) foreign savings (the negative of the current account deficit) are fixed in foreign currency, an outcome that is achieved through changes in the real exchange rate; and (3) real gross fixed capital formation is fixed, and household savings are adjusted accordingly. In addition, we assume that both labor and capital are perfectly mobile across sectors.

\subsection{Data}

The Social Accounting Matrix (SAM) used in this study was constructed using four sources of information: an existing SAM for 2011 (Escobar, 2015), Supply and Use Tables (SUT) from the Central Bank of Guatemala (BANGUAT) for 2011 (BANGUAT, 2011); the relative structure of remunerations of capital and land found on the GTAP database; and the 2011 Living Standards Measurement Study (LSMS), the Encuesta Nacional de Condiciones de Vida or ENCOVI (INE, 2011). The disaggregation of our Guatemalan SAM coincides with that of the rest of the model database and, as shown in table 1, consists of eight activities and 32 commodities. The factors are split into unskilled and skilled labor, (private) capital, and natural resources (two types: agricultural land and other natural resources used in forestry, fishing, and extractive industries).

Using the 2011 LSMS (ENCOVI), households were classified into four types: rural poor, rural non-poor, urban poor, and urban non-poor. Poverty was determined using the official 2011 poverty line (INE, 2011). Information from the household survey allowed us to estimate labor income, consumption, and most transfers from other agents, according to each household type.

\footnotetext{
${ }^{3}$ SEEA is the first international standard for environmental-economic statistics (UN et al., 2014). SEEA provides a connection between physical information about the environment and economic transactions in a way that is consistent with the definitions and classifications of the System of National Accounts.

${ }^{4}$ Although our assumption better reflects the reality of Guatemala, we are aware that it is difficult to conduct a welfare analysis given that government consumption is not a determinant of household utility. For welfare analysis, a closure with fixed government consumption and real savings would be preferable, using direct taxes to clear the government budget.
} 
Table 1 . Commodity and economic activity and transaction aggregation for the micro SAM

\begin{tabular}{|c|c|c|c|}
\hline Category & Item & Category & Item \\
\hline \multirow[t]{7}{*}{ Activities (7) } & Agriculture & Products (32) - cont. & Sugar \\
\hline & Livestock & & Farinaceous products \\
\hline & Forestry and fishing & & Dairy products \\
\hline & Other primary activities & & Other food products \\
\hline & Food processing & & Beverages \\
\hline & Other manufacturing & & Other manufacturing \\
\hline & Services & & Electricity and water \\
\hline \multirow[t]{23}{*}{ Products (32) } & Coffee & & Hotels and restaurants \\
\hline & Bananas & & Other services \\
\hline & Corn & & Trade and transport margins \\
\hline & Beans & & Tax, activities \\
\hline & Cereals and legumes & & Subsidy, activities \\
\hline & Roots and tubers & & Tax, commodities \\
\hline & Vegetables & & Subsidy, commodities \\
\hline & Fruit & & Tax, imports \\
\hline & Living plants & & Tax, income \\
\hline & Milk & & Tax, factor income \\
\hline & Eggs & Factors (5) & Labor, skilled \\
\hline & Other animal products & & Labor, unskilled \\
\hline & Firewood & & Capital \\
\hline & Other forestry products & & Land \\
\hline & Fish and fishery products & & Natural resources \\
\hline & Minerals & Institutions (6) & Households, urban poor \\
\hline & Meat and meat products & & Households, rural poor \\
\hline & Prepared and preserved fish & & Households, urban non-poor \\
\hline & $\begin{array}{l}\text { Prepared and preserved } \\
\text { vegetables }\end{array}$ & & Households, rural non-poor \\
\hline & $\begin{array}{l}\text { Animal and vegetable oils } \\
\text { and fats }\end{array}$ & & Government \\
\hline & Grain mill products & & Rest of the world \\
\hline & $\begin{array}{l}\text { Preparations used in animal } \\
\text { feeding }\end{array}$ & & Savings-Investment \\
\hline & Bakery products & Capital account (2) & Change in stocks \\
\hline
\end{tabular}

Source: Authors, with information from BANGUAT (2011). 
Along with the SAM, we estimated: (a) base-year employment by sector, (b) base-year water use, and (c) a set of elasticities (for production, consumption, and trade). In order to estimate employment by sector, we used the LSMS (ENCOVI) 2011 to disaggregate by activity and labor category (skilled and unskilled). ${ }^{5}$ Thus, given the use of physical labor quantities for model calibration, our model assumes that factor remuneration can differ across activities. In other words, each activity pays an activity-specific wage. ${ }^{6}$ For water use, we extracted estimates from the Guatemalan SEEA. In the Guatemalan SEEA, water flow accounts quantify the abstraction of water from the environment to the economy, the water flow within the economy in terms of supply and use by industries and households, and water flow back to the environment.

In turn, income elasticities of demand were estimated using microdata from LSMS (INE, 2011). For value-added elasticities, we used those provided by GTAP (Narayanan et al., 2012). Finally, for production and for Armington and CET elasticities, we used Annabi et al.'s (2006) estimates for economies similar to that of Guatemala in terms of GDP per capita.

\subsection{Guatemala's economic structure}

From the SAM, ${ }^{7}$ we extracted key features of the Guatemalan economy that help clarify the results of our simulations. The services sector contributes to more than 65 per cent of GDP, followed by industry and agriculture (table 2). Crop production uses more than 21 billion cubic meters of water, followed by forestry and fishing with 930.9 million cubic meters. Livestock and other primary activities use less, with 111.8 and 5.4 million cubic meters of water, respectively.

Food products (36.1 per cent) and other industries (15.4 per cent) make up the majority of exports. Coffee and bananas represent 9.2 per cent and 3.7 per cent of exports of agricultural products, respectively. A total of 68 per cent of coffee is exported (see table 2). The 'other manufacturing' category accounts for 80.2 per cent of total imports. Interestingly, the import-penetration rate is very high for cereals (more than 80 per cent). As a result of the importance of corn in the Guatemalan diet, it is important to emphasize that 29.4 per cent of the national consumption is covered by imports.

Table 3 shows the factor shares in total value-added by sector. For example, agriculture uses unskilled labor relatively intensively -61.7 per cent of value-added represents payments to unskilled labor. In addition, agricultural sectors are obviously land users. On the other hand, manufacturing and services industries employ skilled labor relatively more intensively. In section 4 , this information will be useful to analyze the results from the CGE simulations.

Generally speaking, households draw their income from labor, capital, land, other natural resources, and transfers. Poor urban households mainly receive income from unskilled labor (47.9 per cent), with skilled labor and capital income making up the remainder. Almost two-thirds of poor rural household income comes from unskilled labor; the remainder comes from remittances and transfers from the government. For non-poor rural households, labor income accounts for 61 per cent of total income: 41 per cent for unskilled and 20 per cent for skilled labor. For this group of households,

\footnotetext{
${ }^{5}$ Skilled workers are those with nine or more years of schooling.

${ }^{6}$ In fact, the PEP-1-1 model was also extended to allow for the use of physical - as opposed to efficiency - units for labor.

${ }^{7}$ For additional detail on the construction of the SAM, see Vargas et al. (2016).
} 
Table 2. Structure by sector (\%)

\begin{tabular}{|c|c|c|c|c|c|c|c|}
\hline Product & Value added & Production & Employment & Exports & Exports-output ratio & Imports & Imports-demand ratio \\
\hline Coffee & 1.6 & 1.2 & 4.1 & 9.2 & 95.0 & 0.0 & 0.4 \\
\hline Bananas & 1.0 & 0.7 & 2.5 & 3.7 & 59.1 & 0.0 & 0.2 \\
\hline Beans & 0.7 & 0.5 & 1.8 & 0.0 & 0.5 & 0.1 & 5.9 \\
\hline Cereals and legumes & 0.1 & 0.1 & 0.2 & 0.0 & 1.2 & 1.2 & 84.0 \\
\hline Fruit & 0.7 & 0.5 & 1.7 & 1.8 & 32.3 & 0.3 & 17.2 \\
\hline Living plants & 1.4 & 1.0 & 3.6 & 1.2 & 17.6 & 0.7 & 15.7 \\
\hline Milk & 0.2 & 0.2 & 0.3 & 0.0 & 0.0 & 0.0 & 0.0 \\
\hline Eggs & 0.5 & 0.5 & 1.0 & 0.0 & 0.1 & 0.0 & 1.5 \\
\hline Fish and fishery prod. & 0.2 & 0.2 & 0.5 & 0.6 & 42.6 & 0.1 & 22.8 \\
\hline Minerals & 3.0 & 2.0 & 0.3 & 9.9 & 78.4 & 0.7 & 27.8 \\
\hline Meat \& meat products & 1.8 & 2.2 & 0.8 & 0.4 & 2.6 & 0.7 & 7.8 \\
\hline Prepared \& preserved fish & 0.1 & 0.1 & 0.0 & 0.3 & 38.2 & 0.2 & 52.6 \\
\hline Prepared and preserved vegetables & 0.2 & 0.3 & 0.1 & 0.8 & 40.5 & 0.6 & 46.5 \\
\hline
\end{tabular}


Table 2. Continued

\begin{tabular}{|c|c|c|c|c|c|c|c|}
\hline Product & Value added & Production & Employment & Exports & Exports-output ratio & Imports & Imports-demand ratio \\
\hline Animal and vegetable oils and fats & 0.7 & 0.8 & 0.3 & 2.7 & 48.3 & 1.9 & 52.8 \\
\hline Grain mill products & 1.7 & 2.0 & 0.8 & 0.3 & 2.5 & 0.8 & 9.1 \\
\hline Preparations used in animal feeding & 0.3 & 0.4 & 0.1 & 0.3 & 12.2 & 0.2 & 15.6 \\
\hline Bakery products & 2.6 & 3.2 & 1.2 & 0.6 & 2.4 & 0.5 & 3.6 \\
\hline Sugar & 1.4 & 1.7 & 0.7 & 5.5 & 44.7 & 0.0 & 0.1 \\
\hline Farinaceous products & 0.2 & 0.2 & 0.1 & 0.2 & 13.4 & 0.1 & 9.2 \\
\hline Dairy products & 0.7 & 0.8 & 0.3 & 0.1 & 1.5 & 0.8 & 20.3 \\
\hline Other food products & 0.9 & 1.1 & 0.4 & 2.1 & 24.2 & 2.2 & 39.0 \\
\hline Beverages & 0.3 & 0.5 & 0.3 & 0.9 & 21.9 & 0.3 & 16.1 \\
\hline Other manufacturing & 8.8 & 14.2 & 9.1 & 36.1 & 30.3 & 80.2 & 65.6 \\
\hline Electricity and water & 1.9 & 1.8 & 1.6 & 0.2 & 1.7 & 0.4 & 4.8 \\
\hline Hotels \& restaurants & 4.0 & 3.7 & 3.4 & 0.0 & 0.0 & 0.0 & 0.0 \\
\hline Other services & 59.7 & 55.6 & 50.7 & 15.4 & 4.6 & 6.3 & 2.7 \\
\hline Total & 100.0 & 100.0 & 100.0 & 100.0 & 13.1 & 100.0 & 22.5 \\
\hline
\end{tabular}

Notes: VAshr, value-added share (\%); PRDshr, production share (\%); EMPshr, share in total employment (\%); EXPshr, sector share in total exports (\%); EXP-OUTshr, exports as share in sector output

(\%); IMPshr, sector share in total imports (\%); IMP-DEMshr, imports as share of domestic demand (\%).

Source: Authors' calculations. 
Table 3. Factor intensity by sector (\%)

\begin{tabular}{lcccccc}
\hline Activity & $\begin{array}{c}\text { Labor, } \\
\text { skilled }\end{array}$ & $\begin{array}{c}\text { Labor, } \\
\text { unskilled }\end{array}$ & Capital & Land & $\begin{array}{c}\text { Natural } \\
\text { resources }\end{array}$ & Total \\
\hline Agriculture & 6.8 & 61.7 & 14.9 & 16.6 & 0.0 & 100.0 \\
\hline Livestock & 6.5 & 59.4 & 16.1 & 18.0 & 0.0 & 100.0 \\
\hline Forestry and fishing & 6.8 & 58.9 & 16.2 & 16.3 & 1.8 & 100.0 \\
\hline Other primary activities & 7.1 & 25.2 & 40.1 & 0.0 & 27.6 & 100.0 \\
\hline Food processing & 37.4 & 27.0 & 35.5 & 0.0 & 0.0 & 100.0 \\
\hline Other manufacturing & 23.4 & 30.8 & 45.8 & 0.0 & 0.0 & 100.0 \\
\hline Services & 33.7 & 19.4 & 47.0 & 0.0 & 0.0 & 100.0 \\
\hline Total & 29.1 & 26.4 & 41.7 & 2.0 & 0.9 & 100.0 \\
\hline
\end{tabular}

Source: Authors' calculations.

transfers from the rest of the world represent just under a quarter of their income. For urban non-poor households, capital income represents almost half their income, followed by skilled labor (30.3 per cent) and unskilled labor. Non-poor rural households are the main receivers of land income (40.4 per cent of total). ${ }^{8}$ Remaining land income is distributed almost evenly across the other three household categories in the SAM.

Urban non-poor households account for 59.5 per cent of national consumption, and rural non-poor households account for just under one-fifth (18.1 per cent). National consumption by poor households accounts for 22.4 per cent of domestic consumption: 7.8 per cent for households in urban areas and 14.6 per cent in rural areas. Rural poor households spend 62.1 per cent of their income on consumption. The distribution of spending is different across households as shown in table 4. Indeed, for non-poor households, the proportion of food consumption is lower, specifically for urban non-poor households, where it represents less than a third (31.1 per cent) of total consumption.

\section{Scenarios and results}

\subsection{Scenarios}

In the first scenario (named tfpagr), we analyzed results from a simulation of reduced agricultural production of crops and livestock as a result of climate change. 'Climate change' is intended here to include changes in mean temperature, variability of climate, extreme events, water availability, mean sea-level rise, pests, and diseases (Gornall et al., 2010). Specifically, and according to CEPAL (2013) estimates, we assumed a negative scenario of climate change in which the production of grains was reduced in corn, in beans, and in wheat. ${ }^{9}$ Technically, and due to the lack of better data, we estimated a scenario in which the TFP of total agriculture production dropped by around 8 per cent. ${ }^{10}$

\footnotetext{
${ }^{8}$ When building the SAM, we used the LSMS ENCOVI 2011 to compute the distribution of factor incomes across our four household categories.

${ }^{9}$ This scenario assumes an increase in temperature by $3.5^{\circ} \mathrm{C}$ with a 30 per cent decrease in rainfall, which projects a fall in the yield of maize up to 34 per cent, of beans up to 66 per cent and of rice up to 27 per cent.

${ }^{10}$ Needless to say, this is a rough approximation, given that we cannot simulate a decrease in TFP that affects the production of selected crops.
} 
Table 4. Consumption composition of each household group (\%)

\begin{tabular}{|c|c|c|c|c|}
\hline Product & $\begin{array}{l}\text { Urban, } \\
\text { poor }\end{array}$ & $\begin{array}{l}\text { Rural, } \\
\text { poor }\end{array}$ & $\begin{array}{l}\text { Urban, } \\
\text { non-poor }\end{array}$ & $\begin{array}{l}\text { Urban, } \\
\text { non-poor }\end{array}$ \\
\hline Coffee & 0.0 & 0.0 & 0.0 & 0.0 \\
\hline Bananas & 1.4 & 1.5 & 0.6 & 0.8 \\
\hline Corn & 4.3 & 4.7 & 2.6 & 3.3 \\
\hline Beans & 3.8 & 6.8 & 0.4 & 2.4 \\
\hline Cereals and legumes & 0.2 & 0.3 & 0.1 & 0.1 \\
\hline Roots and tubers & 2.4 & 2.5 & 1.0 & 1.5 \\
\hline Vegetables & 7.0 & 7.4 & 3.0 & 4.9 \\
\hline Fruit & 1.7 & 1.7 & 0.9 & 1.2 \\
\hline Living plants & 0.2 & 0.2 & 0.2 & 0.2 \\
\hline Milk & 0.1 & 0.0 & 0.3 & 0.1 \\
\hline Eggs & 1.1 & 0.6 & 1.3 & 1.0 \\
\hline Other animal products & 0.0 & 0.0 & 0.0 & 0.0 \\
\hline Firewood & 1.3 & 1.2 & 0.8 & 0.9 \\
\hline Other forestry products & 1.6 & 2.3 & 0.2 & 0.9 \\
\hline Fish and fishery products & 0.5 & 0.7 & 0.1 & 0.3 \\
\hline Minerals & 0.1 & 0.1 & 0.1 & 0.1 \\
\hline Meat and meat products & 6.0 & 6.5 & 3.2 & 3.8 \\
\hline Prepared and preserved fish & 0.3 & 0.3 & 0.2 & 0.2 \\
\hline Prepared \& preserved vegetables & 0.4 & 0.5 & 0.5 & 0.6 \\
\hline Animal \& vegetable oils and fats & 0.8 & 0.7 & 1.0 & 1.1 \\
\hline Grain mill products & 5.3 & 5.1 & 2.5 & 3.5 \\
\hline Preparations used in animal feeding & 0.2 & 0.3 & 0.1 & 0.2 \\
\hline Bakery products & 4.8 & 11.1 & 6.8 & 9.4 \\
\hline Sugar & 3.1 & 3.8 & 1.0 & 1.8 \\
\hline Farinaceous products & 0.8 & 1.0 & 0.3 & 0.5 \\
\hline Dairy products & 4.0 & 4.0 & 1.7 & 2.5 \\
\hline Other food products & 2.4 & 1.5 & 2.4 & 2.2 \\
\hline Beverages & 1.5 & 1.2 & 1.0 & 1.2 \\
\hline Other manufacturing & 22.5 & 18.7 & 23.0 & 21.9 \\
\hline Electricity and water & 1.0 & 0.8 & 1.0 & 1.0 \\
\hline Hotels and restaurants & 8.4 & 5.2 & 6.5 & 5.3 \\
\hline Other services & 12.8 & 9.3 & 37.3 & 27.3 \\
\hline Total & 100.0 & 100.0 & 100.0 & 100.0 \\
\hline
\end{tabular}

Source: Authors' calculations. 
Table 5. Real macro-indicators (percentage change from base)

\begin{tabular}{lccc}
\hline Item & Base year $^{\mathrm{a}}$ & tfpagr & Drought \\
\hline Absorption & 410,834 & -1.1 & 0.7 \\
\hline Private consumption & 316,528 & -1.4 & 0.1 \\
\hline Fixed investment & 54,910 & 0.0 & 0.0 \\
\hline Government consumption & 37,803 & -0.6 & 6.0 \\
\hline Exports & 98,783 & -2.0 & 0.4 \\
\hline Imports & 138,605 & -1.5 & -0.2 \\
\hline GDP & 371,012 & -1.2 & 0.9 \\
\hline Real exchange rate & 1 & 1.8 & 7.6 \\
\hline
\end{tabular}

Notes: ${ }^{a}$ In this column, the unit is one million quetzales except for the real exchange rate, which is indexed to 1.

Source: Authors' calculations.

Specifically, this fall in TFP was estimated using the coefficients obtained in Letta and Tol (2016) for annual TFP growth rates and temperature changes in poor countries (table 7 , page 34) combined with the variations reported in CEPAL (2013: 25-26).

In the second scenario (named drought), we simulated the effects of a drought that would reduce unregistered water availability for agricultural and non-agricultural activities by 25 per cent. In fact, according to estimates on the total renewable availability of water for Central America conducted by CEPAL (2011), in a scenario where the current trend of increasing emissions is maintained, ${ }^{11}$ the temperature could increase between 3.6 and $4.7^{\circ} \mathrm{C}$, with a regional average of $4.2^{\circ} \mathrm{C}$. For Guatemala, this would mean a 25 per cent reduction in water availability by the year 2050 . Unfortunately, information on total water is unknown for Guatemala. Thus, we assumed that total demand was close to 90 per cent of total supply in the base year. We also had no specific basis for estimating a change in water price because Guatemala does not currently have a market for this resource. The results indicate the likely effects of drought on economic activity, however. ${ }^{12}$ Because of dependence on rainfall for irrigation and lack of investment in irrigation systems, both scenarios are highly relevant for Guatemala.

\subsection{Results}

In the first scenario, we assumed that climate change would have negative effects on agricultural productivity. As expected, under the climate-change scenario, we found negative results in production and exports of crops and livestock and in wages, as well as a drop of 1.2 per cent in real GDP (see tables 5 and 6). Moreover, a drop in production and consumption of agricultural goods and industrial foods increased food insecurity as measured by the value of food production and consumption (see figure 1 and table 7). Interestingly, in order to compensate for the decrease in TFP, employment in agriculture increased. As a result, given that agricultural production tends to use unskilled labor, we found that the decrease in wages was relatively larger for skilled than for unskilled workers. Lower productivity would translate into less competitiveness in international

\footnotetext{
${ }^{11}$ CEPAL estimated water availability using the TURC method (1954), including the difference between rainfall and evapotranspiration (CEPAL, 2011: 103-104).

${ }^{12}$ The sensitivity analysis of results is included in Vargas et al. (2016).
} 
Table 6. Exports and imports by product (percentage change from base)

\begin{tabular}{|c|c|c|c|c|c|c|}
\hline \multirow[b]{2}{*}{ Product } & \multicolumn{3}{|c|}{ Exports } & \multicolumn{3}{|c|}{ Imports } \\
\hline & Base year* & tfpagr & Drought & Base year* & tfpagr & Drought \\
\hline Coffee & 6,578 & -19.2 & -64.5 & 1 & 3.8 & 31.3 \\
\hline Bananas & 2,521 & -12.7 & -44.2 & 4 & 6.3 & 43.9 \\
\hline Corn & 29 & -20.1 & -68.5 & 1,871 & 6.5 & 41.5 \\
\hline Beans & 14 & -4.6 & -18.6 & 176 & 0.8 & 8.9 \\
\hline Cereals and legumes & 4 & -18.2 & -66.0 & 1,707 & -0.1 & 8.2 \\
\hline Roots and tubers & 35 & -21.1 & -70.9 & 25 & 2.0 & 20.9 \\
\hline Vegetables & 1,438 & -16.3 & -63.8 & 59 & -0.7 & 5.0 \\
\hline Fruit & 932 & -20.4 & -69.7 & 380 & 1.7 & 19.1 \\
\hline Living plants & 1,075 & -26.3 & -78.1 & 934 & 4.6 & 40.0 \\
\hline Eggs & 3 & -26.8 & 140.0 & 42 & 3.7 & -10.6 \\
\hline Other animal products & 27 & -19.9 & 98.9 & 1 & 3.2 & -6.2 \\
\hline Other forestry products & 2,635 & -2.8 & 22.5 & 242 & -0.1 & -3.0 \\
\hline Fish and fishery products & 400 & 43.9 & -23.8 & 158 & -3.6 & 6.9 \\
\hline Minerals & 9,445 & 5.8 & 36.8 & 939 & -2.8 & -5.9 \\
\hline Meat and meat products & 335 & 0.1 & 8.9 & 997 & -2.7 & -5.8 \\
\hline Prepared and preserved fish & 194 & 1.5 & 15.1 & 335 & -1.6 & -4.3 \\
\hline Prepared \& preserved vegetables & 671 & 1.1 & 13.3 & 814 & -1.4 & -1.7 \\
\hline Animal \& vegetable oils and fats & 2,314 & 3.0 & 25.8 & 2,700 & -1.8 & -0.7 \\
\hline Grain mill products & 298 & 0.2 & 8.1 & 1,141 & -0.9 & 0.9 \\
\hline $\begin{array}{l}\text { Preparations used in animal } \\
\text { feeding }\end{array}$ & 270 & -4.9 & 19.8 & 340 & -11.1 & 15.7 \\
\hline Bakery products & 455 & 0.5 & 9.1 & 686 & -1.1 & 0.3 \\
\hline Sugar & 4,638 & 0.8 & 12.1 & 7 & -2.0 & -3.8 \\
\hline Farinaceous products & 151 & 0.6 & 10.3 & 91 & -2.3 & -5.8 \\
\hline Dairy products & 75 & 0.8 & 11.0 & 1,145 & -2.1 & -5.0 \\
\hline Other food products & 1,539 & 1.0 & 12.6 & 3,008 & -1.6 & -2.7 \\
\hline Beverages & 667 & 1.1 & 11.0 & 381 & -2.1 & -4.5 \\
\hline Other manufacturing & 25,639 & 1.2 & 12.6 & 111,119 & -1.6 & -0.8 \\
\hline Electricity and water & 174 & 2.0 & 15.2 & 516 & -1.3 & 1.1 \\
\hline Other services & 15,182 & 1.3 & 11.2 & 8,787 & -2.9 & -6.5 \\
\hline
\end{tabular}

Notes: ${ }^{*}$ In this column, the unit is one million quetzales. Source: Authors' calculations. 


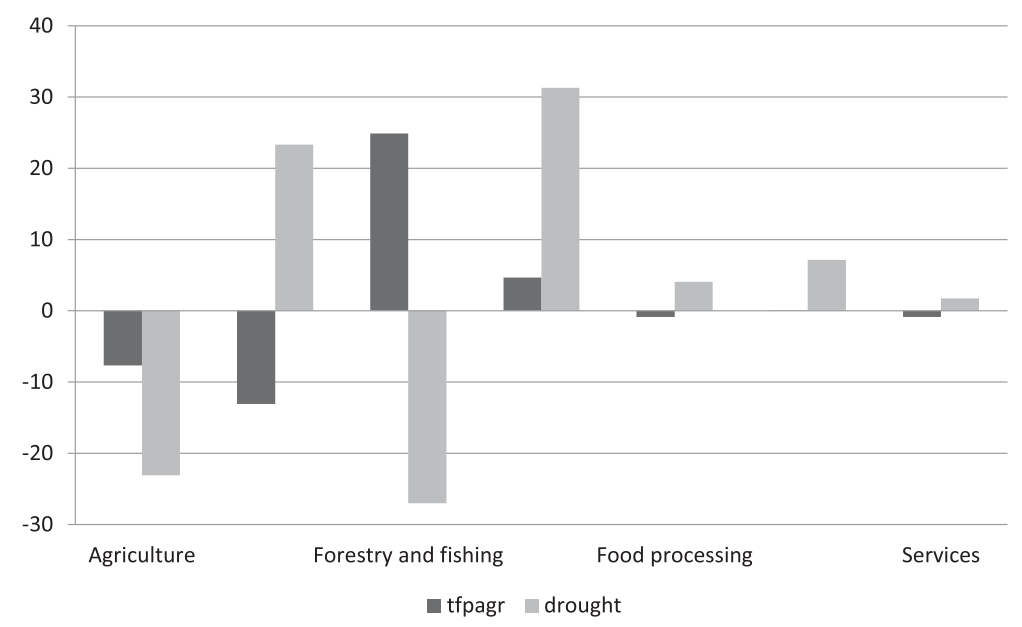

Figure 1 . Value-added by sector (percentage change from base) Source: Authors' calculations.

markets: goods such as corn, beans, and root and tuberous vegetables showed a lower decrease in output compared to exported products such as coffee, bananas, and fruit. Overall, exports would fall in real terms by 2 per cent, even though a depreciation of the real exchange rate would reduce negative effects.

In all cases, given the reduction of domestic output, demand for agricultural products would be partly covered by an increase in imports. In terms of food security (see figure 2), the tfpagr scenario showed an increase in the cereal imports dependency ratio. ${ }^{13}$ In fact, at base-year prices, the share of imports in the overall consumption of cereals increased by 1.9 percentage points. Moreover, another food security indicator such as the value of food (excluding fish) imports over total merchandise exports ${ }^{14}$ also shows a negative behavior. Specifically, it increased from 16.7 in the base year to 17.0 in the tfpagr scenario.

As a result of the decrease in output, the simulation also showed a reduction in fiscal space. As a consequence, and given the clearing mechanism selected for the government budget, government expenditures would have to be reduced in view of lower tax revenues which, in turn, would make less income available to households and decrease consumption.

As a result of higher prices and lower household income, moreover, lower agricultural productivity translated into a decrease in consumption of agricultural goods for each household type (see table 7). Interestingly, corn consumption would only fall in rural areas; in urban areas, the demand for this product is inelastic. The results of this scenario could affect food security for Guatemala's most vulnerable citizens, however. The consumption of beans, which are also important to the Guatemalan diet, decreased

\footnotetext{
${ }^{13}$ It is computed as (cereal imports - cereal exports)/(cereal production + cereal imports - cereal exports $) \times 100$. It tells how much of the available domestic food supply of cereals has been imported and how much comes from the country's own production (FAO, 2017).

${ }^{14}$ Following FAO (2017), this indicator captures the adequacy of foreign exchange reserves to pay for food imports, which has implications for national food security depending on production and trade patterns.
} 

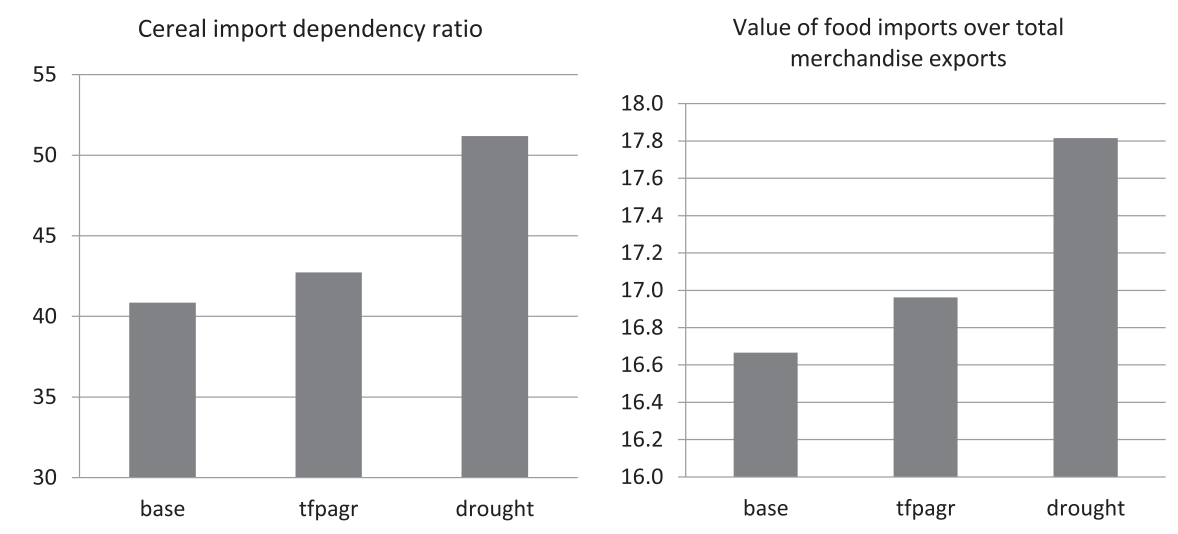

Figure 2. Food security indicators (\%) Source: Authors' calculations.

for all types of households. Again, this behavior resulted from higher prices combined with a decrease in income for all household categories. In terms of income inequality, and given the change in factor incomes described above, urban households showed the largest drop in income (note, too, that urban households have a larger endowment of skilled labor).

In the second scenario, we assessed the effects of a water shortage or drought on agricultural and non-agricultural industries such as forestry and fishing. In our base-year data, water use was concentrated in forestry and fishing and in agriculture (59 per cent of total water use). Thus most negative effects of this shock would be concentrated in these labor-intensive activities. At the macro level, we noted positive effects on output and private consumption.

In this scenario, the decrease in agricultural output promoted the movement of labor out of agriculture (crops) and into activities with higher wages. Specifically, employment in overall agriculture decreased by 16.6 per cent while employment in manufacturing and services increased by 11.2 and 6 per cent, respectively. In addition, once water became scarce, its price became a positive number, also increasing the income of households endowed with land - particularly rural non-poor households. In addition, given the decrease in agricultural output as a result of the decrease in water availability, land rents decreased. Not surprisingly, we also observed a rise in the cost of agricultural production.

Compared to the TFP scenario, the negative effects of drought on forestry and fishing and on agriculture were greater (see figure 1). Additionally, livestock production rose because the use of water in this sector is lower than it is in agriculture. In baseyear data, livestock production did not make significant use of water ${ }^{15}$; intuitively, then, as water became scarcer, there would be a shift toward industries with relatively lower water demands and a respective increase in value-added in those industries. In fact, land would also shift from crop production to livestock. As mentioned, this

\footnotetext{
${ }^{15}$ Specifically, its use of water per quetzal of value added was 2 per cent that of crop production - i.e., 0.7 versus 0.02 cubic meters of water per quetzal of value added.
} 
Table 7. Food consumption by household category (percentage change from base)

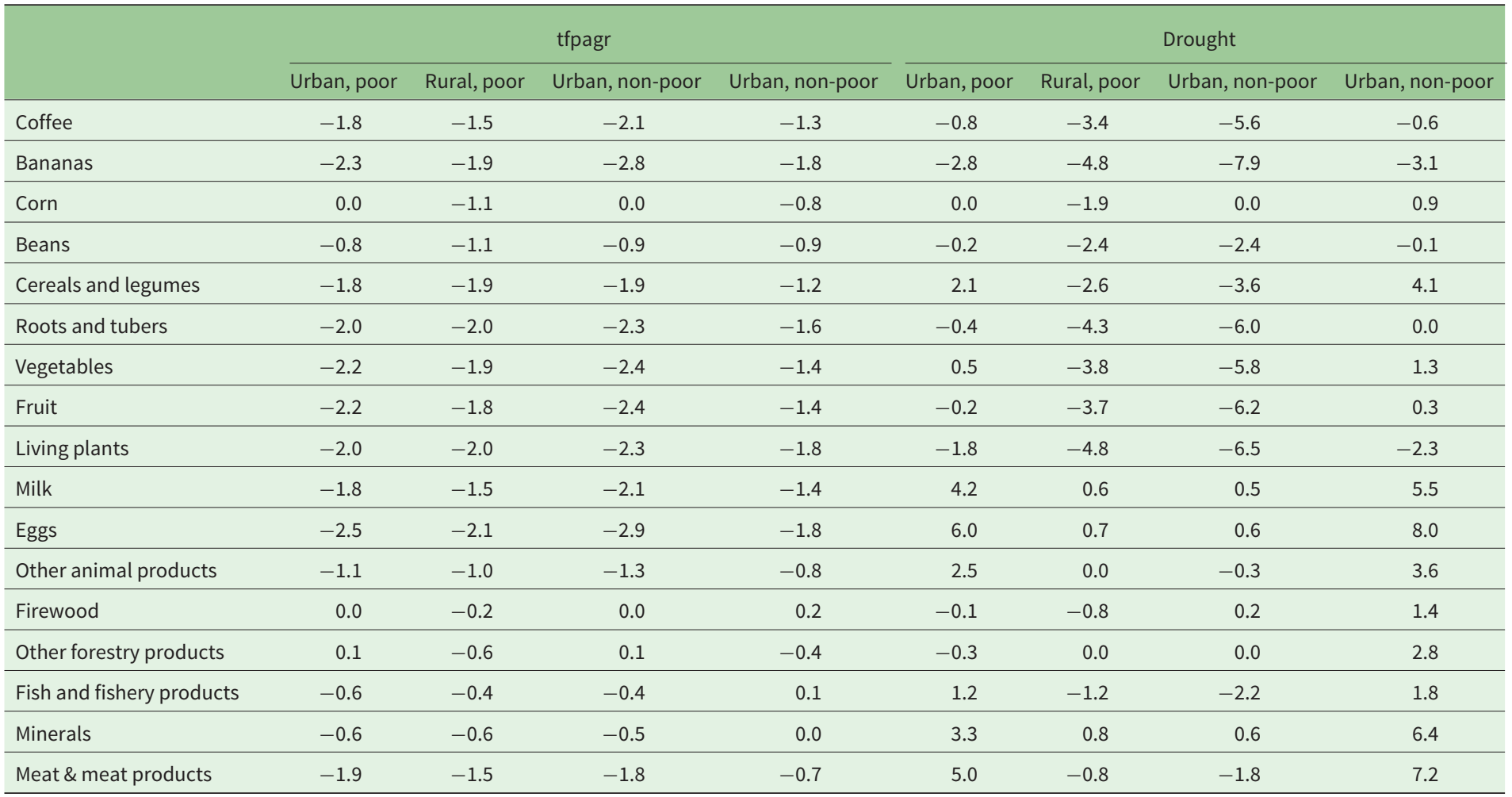


Table 7. Continued.

\begin{tabular}{|c|c|c|c|c|c|c|c|c|}
\hline & \multicolumn{4}{|c|}{ tfpagr } & \multicolumn{4}{|c|}{ Drought } \\
\hline & Urban, poor & Rural, poor & Urban, non-poor & Urban, non-poor & Urban, poor & Rural, poor & Urban, non-poor & Urban, non-poor \\
\hline Prepared \& preserved fish & -1.0 & -0.8 & -1.0 & -0.4 & 2.2 & -0.6 & -1.2 & 3.4 \\
\hline $\begin{array}{l}\text { Prepared \& preserved } \\
\text { vegetables }\end{array}$ & -1.1 & -1.1 & -1.1 & -0.6 & 2.7 & -0.7 & -1.3 & 4.5 \\
\hline $\begin{array}{l}\text { Animal \& vegetable oils and } \\
\text { fats }\end{array}$ & -2.0 & -1.7 & -2.0 & -1.0 & 3.9 & -1.6 & -2.8 & 6.1 \\
\hline Grain mill products & -1.0 & -0.7 & -1.0 & -0.4 & 2.6 & -0.4 & -1.0 & 3.3 \\
\hline $\begin{array}{l}\text { Preparations used in } \\
\text { animal feeding }\end{array}$ & -0.8 & -0.8 & -0.7 & -0.1 & 2.2 & -1.2 & -1.7 & 4.3 \\
\hline Bakery products & -1.2 & -1.2 & -1.2 & -0.6 & 3.4 & -0.5 & -1.1 & 5.9 \\
\hline Sugar & -0.7 & -1.0 & -0.7 & -0.4 & 2.3 & -0.2 & -0.4 & 5.8 \\
\hline Farinaceous products & -1.3 & -1.2 & -1.2 & -0.6 & 3.4 & -0.6 & -1.1 & 6.0 \\
\hline Dairy products & -1.3 & -1.0 & -1.3 & -0.5 & 3.3 & -0.6 & -1.4 & 4.4 \\
\hline Other food products & -1.3 & -1.1 & -1.3 & -0.6 & 3.0 & -0.8 & -1.4 & 5.0 \\
\hline Beverages & -1.2 & -0.9 & -1.1 & -0.3 & 4.0 & -0.1 & -0.6 & 5.6 \\
\hline Other manufacturing & -2.6 & -1.9 & -2.6 & -1.0 & 6.2 & -1.4 & -3.1 & 8.5 \\
\hline Electricity and water & -1.4 & -0.8 & -1.3 & -0.3 & 4.7 & -0.2 & -1.0 & 4.9 \\
\hline Hotels and restaurants & -1.1 & -0.7 & -1.0 & -0.2 & 3.9 & -0.1 & -0.6 & 4.4 \\
\hline Other services & -1.3 & -1.1 & -1.2 & -0.4 & 4.7 & -0.2 & -0.7 & 6.9 \\
\hline
\end{tabular}

Source: Authors' calculations. 
shock would be favorable to other industries and services that do not rely on water consumption.

In this scenario, we also observed a sharp increase in the prices of agricultural and food products, especially bananas, roots and tubers, and beans, because a small share of these products is imported and a low degree of substitution exists between local and imported goods. Given the decrease in domestic output of agricultural products, moreover, we also observed an important increase in imports of food products. Therefore, in terms of food security this scenario shows a significant increase in the share of agrifood consumption covered with imports. In fact, both food security indicators reported in figure 2 showed large increases. For instance, the cereal import dependency ratio increased from 40.9 in the base year to 51.2 in the drought scenario. In turn, the value of food imports over total merchandise exports increased by 1.1 percentage points.

Not surprisingly, agricultural exports also decreased. Thus, given their relevance as a source of foreign exchange (see table 2), we saw a depreciation of the real exchange rate required to maintain the current account balance fixed in foreign currency. In fact, given the substitution of imported food products for local ones, depreciation of the real exchange rate helped to contain increased demand for imports and improved the performance of exports for non-agricultural products (see table 7).

Overall, this scenario imposes considerable risk to food security of households that live in rural areas - i.e., to the population with the highest levels of poverty and malnutrition - who depend on their own production of food products. Indeed, our results show a decrease in food output combined with an increase in the relative price of food products.

\section{Conclusions}

There is consensus that climate change poses an imminent risk to development in countries around the world, but there are few analyses of its potential impact. This study provides some insights into the effects of climate risks for Guatemala. Specifically, we evaluated the impact that droughts would have on growth, household income, and food security, and we found that the most negative effects would be concentrated in agriculture because of its use of water. In fact, our results show a sharp increase in prices of agricultural and food products. Given the decrease in domestic output of food products, in addition, imports of food products would increase. Consequently, a drought scenario would impose considerable risks to food security.

In addition, we simulated a reduction in agricultural productivity related to climate change. In this case, we found negative results in production and exports of agriculture and a drop of 1.2 per cent in real GDP. Interestingly, employment in agriculture increased in order to compensate for the decrease in productivity. In turn, as a result of higher food prices and lower household income, indicators of food security deteriorated.

Our results also show the relevance of creating a legal framework to govern water resources. Guatemala could consequently draw from the experience of Australia which, because of its history of megadroughts, has reformed its water-distribution system. First, federal and state governments reached an agreement (the Intergovernmental Agreement on a National Water Initiative) to create a national water market. The idea behind this distribution system was that 'water entitlements are expressed as a share of the available resource rather than as a specified quantity of water' (Peel and Choy, 2014).

In short, despite Guatemala's National Irrigation Policy, the framework is incomplete because no water-distribution system exists that prioritizes strategic economic activities 
as a guarantee of food security. Our results suggest the importance of correctly managing natural resources such as agricultural land and water. In fact, given Guatemala's large rural population, natural resources can support development and have a positive impact on the life of the country's citizens. Without proper policies, frameworks, and oversight, however, negative shocks arising from climate change have the potential to produce significant negative effects.

Acknowledgements. This work was carried out with financial and scientific support from the Partnership for Economic Policy (PEP), with funding from the Department for International Development (DFID) of the United Kingdom (or UK Aid), and the Government of Canada through the International Development Research Center (IDRC). We are grateful to Hélène Maisonnave for her comments and suggestions. The usual disclaimer applies.

\section{References}

Annabi N, Cockburn J and Decaluwé B (2006) Functional forms and parametrization of CGE models. PEP-MPIA Working Paper 4.

Banerjee O, Cicowiez M, Horridge M and Vargas R (2016) A conceptual framework for integrated economic-environmental modeling. Journal of Environment and Development 25, 276-305.

BANGUAT (Banco de Guatemala) (2011) Sistema de Cuentas Nacionales 1993 -SCN93- Año Base 2001 (Cuadros Estadísticos), Tomo II. Guatemala City, Guatemala: Banco de Guatemala (in Spanish).

Berck P, Robinson S and Goldman G (1990) The use of computable general equilibrium models to assess water policies. Working Paper Series, Department of Agricultural and Resource Economics, UC Berkeley, California.

Cabrera M and Delgado M (2010) Implicaciones de la Política Macroeconómica, los Choques Externos y los Sistemas de Protección Social en la Pobreza, la Desigualdad y la Vulnerabilidad en América Latina y el Caribe. Mexico, DF: Comisión Económica para Latinoamérica y El Caribe (CEPAL) (in Spanish).

CEPAL (Comisión Económica para América Latina y El Caribe) (2011) La economía del cambio climático en Centroamérica, Reporte técnico 2011. Mexico, DF: Sede Subregional de la CEPAL en México (in Spanish).

CEPAL (Comisión Económica para América Latina y El Caribe) (2013) Impactos Potenciales del Cambio Climático sobre los Granos Básicos en Centroamérica. Mexico, DF: Sede Subregional de la CEPAL en México (in Spanish).

Decaluwé B, Lemelin A, Robichaud V and Maisonnave H (2013) PEP-1-1. The PEP Standard SingleCountry, Static CGE Model. Available at https://www.pep-net.org/pep-standard-cge-models.

Escobar P (2015) Efectos distributivos de las vulnerabilidad externas en Guatemala (Master's thesis). Universidad Nacional de La Plata, La Plata, Argentina (in Spanish).

FAO (2017) FAOSTAT. Food and Agriculture Organization of the United Nations. Available at http://www. fao.org/faostat/en/\#home.

Gornall J, Betts R, Burke E, Clark R, Camp J, Willet J and Wiltshire A (2010) Implications of climate change for agricultural productivity in early twenty-first century. Philosophical Transactions of the Royal Society 365, 2973-2989.

IARNA (2012) Análisis Sistémico de la Deforestación en Guatemala y Propuesta de Políticas para Revertirla. Guatemala: Instituto de Agricultura, Recursos Naturales y Ambiente de la Universidad Rafael Landívar (in Spanish).

IARNA (Instituto de Investigación y Proyección sobre Ambiente Natural y Sociedad, Universidad Rafael Landívar). McGill University, and Instituto Interamericano de Cooperación para la Agricultura (IICA) (2015) Food Insecurity and Under-Nutrition in Guatemala, Final Report. Guatemala City, Guatemala: Universidad Rafael Landívar (in Spanish).

INE (2011) Encuesta Nacional de Condiciones de Vida 2011 (Data file). Instituto Nacional de Estadística. Available at https://www.ine.gob.gt (in Spanish).

IPCC (Intergovernmental Panel on Climate Change) (2014) Food security and food production systems. In Climate Change 2014 - Impacts, Adaptation and Vulnerability. Part A: Global and Sectoral 
Aspects. Working Group II Contribution to the IPCC Fifth Assessment Report. Cambridge: Cambridge University Press, pp. 485-534.

Juana JS, Strzepek KM and Kirsten JF (2011) Market efficiency and welfare effects of inter-sectoral water distribution in South Africa. Water Policy 13, 220-231.

Kreft S, Eckstein D, Dorsch L and Fischer L (2015) Global Climate Risk Index 2016. Briefing Paper, Germanwatch, Bonn, Germany.

Letta M and Tol RSJ (2016) Weather, climate and total factor productivity. Working Paper Series 10216, Department of Economics, University of Sussex.

MAGA (2013) Diagnóstico Nacional de Riego de Guatemala. Guatemala City, Guatemala: Ministerio de Agricultura, Ganadería y Alimentación (in Spanish).

Montaud JM, Pecastaing N and Tankari M (2017) Potential socio-economic implications of future climate change and variability for Nigerien agriculture: a countrywide dynamic CGE-microsimulation analysis. Economic Modelling 63, 128-142.

MSPAS (Ministerio de Salud Pública y Asistencia Social), INE (Instituto Nacional de Estadística), and ICEF International (2016) Encuesta Nacional de Salud Materno Infantil 2014-2015. Informe Final, Guatemala City, Guatemala: MSPAS/INE/ICF (in Spanish).

Narayanan G, Badri A and McDougall R (2012) Global Trade, Assistance, and Production: The GTAP 8 Database. West Lafayette, IN: Center for Global Trade Analysis, Purdue University.

Palmieri M and Delgado H (2011) Análisis Situacional de la Malnutrición en Guatemala: Sus Causas y Abordaje. Guatemala City, Guatemala: Programa de las Naciones Unidas para el Desarrollo (in Spanish).

Peel J and Choy J (2014) Water governance and climate change. Drought in California as a lens on our climate future. Available at http://waterinthewest.stanford.edu/sites/default/files/Water\%20Governance\% 20and\%20Climate\%20Change_final2.pdf.

Rosegrant M, Koo J, Cenacchi N, Ringler C, Robertson R, Fisher M and Sabbagh P (2014) Food Security in a World of Natural Resource Scarcity, The Role of Agricultural Technologies. Washington, DC: International Food Policy Research Institute.

Rutten M, Shuttes L and Meijerink G (2013) Sit down at the ball game: how trade barriers make the world less food secure. Food Policy 38, 1-10.

Sassi M and Cardaci A (2013) Impact of rainfall pattern on cereal market and food security in Sudan: stochastic approach and CGE model. Food Policy 43, 321-331.

Seung CK, Harris TR and MacDiarmid TR (1997) Economic impacts of surface water redistribution policies: a comparison for a supply-determined SAM and CGE models. Journal of Regional Analysis and Policy 27, 55-76.

Sudarshan C, Naranpanawa A, Bandara JS and Sarker T (2017) A general equilibrium assessment of climate-change-induced loss of agricultural productivity in Nepal. Economic Modelling 62, 43-50.

Tirado M, Clarke R, Jaykus L, McQuatters-Gollop A and Frank J (2010) Climate change and food safety: a review. Food Research International 43, 1745-1765.

UNESCO (2012) The United Nations World Water Development Report 4. Paris: UNESCO.

UNESCO (2013) Global Water Resources Under Increasing Pressure From Rapidly Growing Demands and Climate Change. New York, NY: UNESCOPRESS.

UN (United Nations), EU (European Union), FAO (Food and Agriculture Organization of the United Nations), IMF (International Monetary Fund), OECD (Organization for Economic Cooperation and Development), The World Bank (2014) System of Environmental-Economic Accounting 2012 Central Framework. New York, NY: United Nations. Available at https://unstats.un.org/unsd/ envaccounting/seearev/seea_cf_final_en.pdf.

UN (2016) Millennium Development Goals Indicators [Data list]. United Nations Statistics Division. Available at http://mdgs.un.org.

Vargas R (2009) Análisis de las formas de aprovisionamiento de agua por parte de la familias guatemaltecas y su caracterización e implicaciones económicas, basado en el manejo de microdatos de Encovi 2006. (Tesis de licenciatura). Universidad de San Carlos de Guatemala, Guatemala (in Spanish).

Vargas R, Cabrera M, Escobar P, Hernández V, Cabrera J and Guzmán V (2016) Food vulnerability in Guatemala: a static general equilibrium analysis. PEP-MPIA Final Report 12867.

Vásquez W (2008) Guatemala. In Vos R, Ganuza E, Lofgren H, Sánchez MV and Díaz-Bonilla C (eds). Políticas Públicas para el Desarrollo Humano: ¿`Cómo Lograr los Objetivos de Desarrollo del Milenio 
en América Latina y el Caribe? Washington, DC: UNDP, UN-DESA and World Bank (in Spanish), pp. 451-476.

Watson PS and Davies S (2011) Modeling the effects of population growth on water resources: a CGE analysis of the South Platte River Basin in Colorado. Annals of Regional Science 46, 331-348.

Wiebelt M, Breisinger C, Ecker O, Al-Riffai P, Robertson R and Thiele R (2013) Compounding food and income insecurity in Yemen: challenges from climate change. Food Policy 43, 77-89.

World Bank (2016) 2016 World Development Indicators. Washington, DC: International Bank for Reconstruction and Development/The World Bank.

Cite this article: Vargas R, Cabrera M, Cicowiez M, Escobar P, Hernández V, Cabrera J, Guzmán V (2018). Climate risk and food availability in Guatemala. Environment and Development Economics 23, 558-579. https://doi.org/10.1017/S1355770X18000335 